Использование ЭФУ на уроках русского языка способствует формированию коммуникативной и информационной компетенций у обучающихся, активности, самостоятельности, духовности и нравственных ориентиров.

Таким образом, активное использование ЭФУ приводит к изменению в содержания образования, технологии обучения и отношениях между участниками образовательного процесса.

Список литературы:

1. Агеев В.Н. Электронная книга: новое средство социальной коммуникации - Москва, 1997. - С. 3 - 231.

2. Масленикова О.Н. Работа с электронной формой учебника истории. Москва, 2016. - С. 3 - 51.

3. Родин В.П. Создание электронного учебника: концепция и способ реализации [Текст]: учеб.издание / В.П. Родин. - М.: Венец, 2008. - 31 с.

4. Система. Урок. Анализ. Ю.А. Конаржевский. - 2-е изд. - Псков: ПОИКПРО, 2012. - 400 с.

5. Тоискин В.С., Красильников В.В. Теоретические основы разработки электронных образовательных изданий (антропологический подход) [Текст]: учеб.пособ. / В.С. Тоискин, В.В. Красильников. - Ставрополь: СГПИ, 2010. - 108 с.

6. http://efu.drofa.ru/what-is-electroni-textbook/faq.php

7. https://lecta.ru/help/efu_about\#

8. $\quad$ https://normativ.kontur.ru/document?moduleId=1\&documentId=244954

\title{
Песенные тексты как отражение гражданской позиции
}

Павлов Ф.С., студент, Технический институт (филиал) Северо-Восточного федерального университета, 2. Нерюнгри

E-mail: errormacro438@gmail.com

Научный руководитель: стариий преподаватель Желябина А.Г.

В настоящем исследовании рассматриваются песенные тексты популярных хипхоп исполнителей США и Великобритании, и проводится их сравнительносопоставительный анализ с целью изучения гражданской позиции авторов.

Хип-хоп в последние годы занимает нишу одного из особенно популярных жанров среди молодого поколения Соединенных Штатов и Великобритании. Этот жанр музыки является превосходным средством выражения собственной точки зрения его исполнителей. Данное направление призвано формировать у молодежи собственную гражданскую позицию, также его отличает возможность через использование различных языковых средств и приёмов говорить на острые вопросы, поднимать наболевшие темы на языке понятном и доступном различным социальным слоям населения. 
Песенные тексты этого направления музыки более чем на половину состоят из разговорной, просторечной лексики.

Материалом исследования послужили песенные тексты исполнителей США и Великобритании, а именно

Термин "гражданская позиция" не имеет чёткого определения. Учёныелингвисты расходятся в его дефиниции, и поскольку определяющим словом в этом термине является слово «позиция», согласно словарю Ожегова оно может означать точку зрения, мнение в каком-либо вопросе [1]. Соответственно данный термин может быть интерпретирован так: гражданская позиция - это точка зрения отдельно взятого человека по какому-либо политическому вопросу

Песенный текст - вербальная часть песни, поддающаяся подробному анализу, именно через текст исполнитель доносит до слушателя основную мысль, заложенную в своём произведении. [3]

В ходе исследования песенных текстов американских исполнителей было установлено, что одной из значимых социальных проблем США является дискриминация по расовому признаку.

Хип-хоп коллектив Tribe Called Quest в своей песне "We The People", название которой является прямой отсылкой к конституции США, использует следующие выразительные средства:

"All you Black folks, you must go; All you Mexicans, you must go..."- повествование в припеве ведётся как бы от лица государства, угрожающего депортацией афроамериканской и мексиканской части населения, исходят эти угрозы ни от кого иного, как от новоизбранного президента Соединённых Штатов Америки, Дональда Трампа, поскольку он представляет правое движение.

"You in the killing-off-good-young-nigga mood", использование сленгизма «nigga» политически некорректно, подчёркивает уничижительное обращение к темнокожему населению страны. Такое обращение допустимо только в среде самих афроамериканцев. Эта строка указывает на случаи полицейской жестокости в отношении безоружных чернокожих американцев, как-то: убийство 17 летнего Трейвона Мартина в 2012 году, убийство Фредди Грэя в 2015 и другие.

В следующей песне американского исполнителя Джо-Вон Ви́ржини Скотта, более известного под псевдонимом Joey Bada\$, рассматриваются те же самые проблемы, что и в предыдущем треке, его гражданская позиция выражена в песне под название "Land of the Free" (англ. Земля свободы). В данном тексте отражена горькая для афроамериканцев часть истории Америки, автор хочет повлиять на будущее Соединённых Штатов.

Песня была представлена 20 января 2017 года в день рождения исполнителя совпавшего с днём инаугурации Дональда Трампа.

На обложке песни изображён исполнитель в свитере с надписью "Make Amerikkka Suck Again", что является критикой избирательной компании Дональда Трампа с похожим слоганом "Make America Great Again", ведь по мнению большого количества населения (исполнителя в частности) Дональд Трамп является ярым приверженцем правого движения. В этом треке проблемы государства нашли отражение в следующих строчках:

"Three K's, two A's in AmeriKKКа" слово "Аmerica" написанное через три буквы "K" - это популярный выразительный приём, используемый в песенных текстах этого жанра ещё с 90-х годов, он может иметь несколько значений, например: три буквы "K" 
могут указывать на одноимённую ультраправую организацию США "Ku-Klux-Klan" сокращённо "KKK". Также этот он может указывать на высокий уровень коррупции в правительстве США, что мы и видим в данной песне.

Строкой "Still got the last names of our slave owners" исполнитель отсылает к истории Америки, когда чернокожих в качестве рабов завозили из Африки в США. Рабовладельцы давали им свои собственные фамилии, тем самым лишая их собственного исторического и культурного прошлого. Афроамериканцы до сих пор эти фамилии носят как свои собственные.

"Trickery in the system, put my niggas in prison" данный текст говорит о судебной власти США, которая в большинстве случаев настроена против афроамериканцев и других представителей расовых и этнических меньшинств, несмотря на то, что государство активно продвигает идею того, что "правосудие слепо".

В тексте "Obama just wasn't enough, I just need some more closure" певец повествует о единственном темнокожем президенте за всю историю Америки, который не смог оправдать ожидания чернокожего населения, оставив их проблемы нерешенными.

В Великобритании ситуация обстоит иначе. Если в США основной проблемой, отражённой в песенных текстах, является проблема дискриминации темнокожего населения страны, то в Британии основной темой песен стала внешняя политика государства, проблемы бедного и богатого слоёв общества.

B песенном тексте под названием "ill Manors" британского исполнителя Бе́нджамина Пола Баллэнс Дрю, более известного под псевдонимом Plan B, нашла отражение данная проблема, кроме того, в тексте можно заметить завуалированную критику избирательной компании Дэвида Кэмерона, бывшего премьер-министра Великобритании. Данная музыкальная композиция является саундтреком к одноимённому мюзиклу, продюсером которого выступил автор.

"Let's all go on an urban safari" повествование в этой строке ведётся как бы от лица богатых жителей страны, которые собираются на сафари в бедные районы Лондона. В тексте подразумевается, что с бедным населением нужно обращаться как с опасными животными, потому что от них можно ожидать чего угодно.

Текстом "He's got a hoodie on give him a hug" Дрю критикует компанию Дэвида Кэмерона "Hug a hoodie", в которой экс-премьер призывал население страны обнять бедную молодёжь, часто носящую капюшоны (hoodie). Исполнитель считает, что обнимать кого-либо в неблагополучных районах страны - это не самая хорошая идея, по этой причине данная компания Кэмерона выглядит, мягко говоря, глупой и ничем иным как обман, чтобы набрать голоса либералов на выборах.

"Who closed down the community centre?; I killed time there, used to be a member;" - прямое указание на закрытие Дэвидом Кэмероном этих самых "общественных центров", людям стало негде проводить досуг, что повысило уровень преступности в этих кварталах.

Строка "London's burning, I predict a riot" отсылает к великому лондонскому пожару 1666 года, после которого выражение "London's burning" используется в Англии как устоявшееся. Однако после 2011 года оно приобрело новый смысл: теперь оно характеризует массовые беспорядки в Лондоне.

"What needs fixing is the system; Not shop windows down in Brixton" в этом тексте исполнитель подразумевает, что простой ремонт зданий, пострадавших во время 
беспорядков в Лондоне, не устранит проблему - ее нужно решать, выполняя требования протестовавших.

В своём треке, носящим громкое название "Bullshit" (англ. Полный бред), Ки́нгсли Джеймс Да́ли (Akala), прямо, открыто поднимает проблемы родного государства: неоправданно высокие налоги, внешняя политика Великобритании, проблемы религии, ложь в СМИ и многое другое.

В строке "They rob the third world of every cent..." поется о том, что времена колонизации были худшими за всю историю человечества. Особенно отличилась Англия, разорившая Африку.

Словами "Now you got third world debt..." исполнитель указывает на задолженность стран третьего мира как результат «работы» мировых экономических организаций, кредитовавших новые независимые государства под огромные проценты, и этим новым государствам пришлось выплачивать долги вместо того, чтобы вкладывать свои деньги на такие важные вещи, как образование и здравоохранение, и это, по мнению исполнителя, является полным бредом.

Акала поет "Most of what you learn in class... Especially regarding the past..." о том, что большинство вещей, которым учат в школе бесполезны и не пригодятся в реальной жизни. Помимо этого, на уроках истории умалчивают о многих вещах, таких как, например, колонизация Африки.

В композиции есть следующие слова: "Farrakhan banned from the country..." о Фаррахане Луисе, лидере организации "Нация Ислама". Ему был запрещён въезд в Великобританию в связи с радикальной деятельностью его организации. Запрет государства на посещение им страны, по мнению певца, конечно же, является бредом.

"All of what they feed us in the news..." используя слово "feed" (англ. кормить), певец указывает на то, что зачастую СМИ "скармливают" своему населению ложную информацию.

В ходе исследования было установлено, что хип-хоп исполнители поднимают в своих текстах различные государственно-значимые проблемы, выражая собственную позицию и видение на происходящие в стране события. Особенности этого песенного жанра позволяют авторам говорить с молодёжью на понятном, доступном им языке, формируя их гражданскую позицию.

Список литературы:

1. Ожегов С.И., Шведова Н.Ю. Толковый словарь русского языка: 80000 слов и словосочетаний. 1997 // Большая энциклопедия Кирилла и Мефодия 2000: Мультимедиа-энциклопедия. М., 2000.

2. Плотницкий Ю.Е. Лингвостилистические и лингволитературные характеристики англоязычного песенного дискурса: дисс.... канд. филол. наук: 10.02.04

3. Полежаева А.Н. Проблемы современного песенного текста: лингвоэкологический аспект: дисс. ...канд. филол. наук : спец. 10.02.01 